\title{
REFORMING THE RULE AGAINST PERPETUITIES: CHOOSING THE MEASURING LIVES
}

\author{
ROBERT J. LYNN*
}

[L]et the lives be never so many, there must be a survivor, and so it is but the length of that life; [for Twisden used to say, the candles were all lighted at once] ....

$\mathbf{R}$ ECENT perpetuities legislation in England, ${ }^{2}$ New Zealand, ${ }^{3}$ and Western Australia ${ }^{4}$ has raised again questions about the selection of measuring lives for the purpose of demonstrating the validity of limitations in deeds, wills, and trusts under the Rule Against Perpetuities. These new statutes are of more than purely comparative interest: The measuring-lives problems encountered under them are the same as those met under American legislation, and English and commonwealth literature ${ }^{5}$ discussing the new statutes has included direct references to the perpetuities reform legislation adopted here in the United States. ${ }^{6}$

Selecting appropriate measuring lives for perpetuities purposes has never been a matter free from difficulty, and it is absurd to suggest that the adoption of a new version of the Rule Against Perpetuities frees us to any appreciable extent from that difficulty. But it is misleading to assert that it is too difficult to select measuring

* B.S. 1942, J.D. 1948, Ohio State University; J.S.D. 1952, Yale University; Professor of Law, Ohio State University; Visiting Professor of Law, University of California at Los Angeles, 1965.

${ }^{1}$ Scatterwood v. Edge, 1 Salk. 229, 91 Eng. Rep. 203 (K.B. 1699).

2 Perpetuities \&: Accumulations Act, 1964, 13 Eliz. 2, c. 55.

${ }^{3}$ Perpetuities Act, 1964, 13 Eliz. 2, No. 47 (N.Z.).

'Law Reform Act (Property, Perpetuities, and Succession), 1962, 11 Eliz. 2, No. 83 (W. Austl.).

'Allan, Perpetuities: Who Are the Lives in Being?, 81 L.Q. REv. 106 (1965); Allan, The Rule Against Perpetuities Restated, 6 U.W. AustL. ANN. I. Rev. 27 (1963); Leach, Perpetuities Reform: London Proposes, Perth Disposes, 6 U.W. Austu. ANN. L. Rev. 11 (1963); Morris \& Wade, Perpetuities Reform at Last, 80 L.Q. REv. 486 (1964); Simes, Reform of the Rule Against Perpetuities in Western Australia, 6 U.W. AUSTL. ANN. L. REv. 21 (1963).

- The Kentucky statute has received particular treatment. See Allan, Perpetuities: Who Are the Lives in Being?, 81 L.Q. REv. 106, $112-14$ (1965); Allan, The Rule Against Perpetuities Restated, 6 U.W. Austh. ANN. L. REv. 27, 45.46 (1963); Leach, supra note 5 , at 17 n.25; Morris \& Wade, supra note 5, at 496, 498-99; Simes, supra note 5, at 24-25. 
lives under a "wait and see" version of the rule.7 Although that assertion is made as a reason for retaining the orthodox rule, the argument supporting the assertion is often overstated. ${ }^{8}$ Certainly the assertion ought not to be decisive on the point, for it is demonstrable that selection of appropriate measuring lives in the more common kinds of perpetuities cases is not too difficult under "wait and see."'

Nevertheless, the difficulties inherent in selecting the measuring lives under reform legislation have already persuaded one jurisdiction to throw the problem back to the orthodox rule. The recent Western Australian "wait and see" statute unhappily provides:

Nothing in this section makes any person a life in being for the purpose of ascertaining the perpetuity period unless that person would have been reckoned a life in being for that purpose if this section had not been enacted.10

In this article I propose (1) to review briefly the selection of measuring lives for the purpose of demonstrating the validity of limitations under the orthodox Rule Against Perpetuities, (2) to demonstrate that the choice of measuring lives has been widened by the new perpetuities statutes (including "wait and see,"11 "cy

'See Jones, Measuring Lives under the Pennsylvania Statutory Rule Against Perpetuities, 109 U. PA. L. REv. 54, 64 (1960); Mechem, Further Thoughts on the Pennsyl-. vania Perpetuities Legislation, 107 U. PA. L. Rev. 965, 976 (1959); Simes, Is the Rule Against Perpetuities Doomed?, 52 MIcH. L. Rev. 179, 186 (1953).

${ }^{8}$ See Leach, Perpetuities Legislation: Hail, Pennsylvania!, 108 U. PA. L. REv. 1124, $1142-47$ (1960).

' See Lynn, A Practical Guide to the Rule Against Perpetuities, 1964 Duke L.J. 207, 219-23, 228-31, 237-39, 242-45.

${ }^{10} \mathrm{Law}$ Reform Act (Property, Perpetuities, and Succession), 1962, 11 Eliz. 2, No. 83, $\$ 7$ (3) (W. Austl.). Even the draftsman of the statute has admitted the weakness of this provision. See Allan, Perpetuities: Who Are the Lives in Being?, 81 L.Q. REv. 106, 109-10 (1965). On the other hand, this approach has been called "fundamentally sound." Morris \& Wade, supra note 5, at 499-501.

11 The first example of a "wait and see" statute was that enacted by Pennsylvania in 1947. It provides: "Upon the expiration of the period-allowed by the common law rule against perpetuities as measured by actual rather than possible events any interest not then vested and any interest in members of a class the membership of which is then subject to increase shall be void." PA. STAT. ANN. tit. 20, $\$ 301.4$ (b) (1950). The Pennsylvania statute has been discussed extensively. Brégy, A Defense of Pennsylvania's Statute on Perpetuities, 23 TEMP. L.Q. 313 (1950); Cohan, The Pennsylvania Wait-and-See Perpetuity Doctrine-New Kernels from Old Nutshells, 28 TEMP. L.Q. 321 (1955); Jones, supra note 7; Leach, Perpetuities Legislation: Hail, Pennsylvania!, 108 U. PA. L. Rev. 1124 (1960); Mechem, supra note 7; Phipps, The Pennsylvania Experiment in Perpetuities, 23 TEMP. L.Q. 20 (1949).

With the enactment of the Perpetuities and Accumulations Act, 1964, 13 Eliz. 2, c. 55, England joined Pennsylvania and those other jurisdictions having a full-scale "wait and see" version of the rule. The English act has a limited "cy pres" feature. Perpetuities 
pres,"12 and "wait and see" coupled with "cy pres"13 statutes), and (3) to suggest a simple version of "wait and see" that leaves the selection of measuring lives where it can be most easily developed-in the hands of the judges, lawyers and commentators ${ }^{14}$ who shape the rule from time to time.

\section{The Measuring Lives Under the Orthodox Rule}

The most frequently quoted statement of the common law Rule Against Perpetuities in orthodox form is that of John Chipman

and Accumulations Act, 1964, 13 Eliz. 2, c. 55, $\$ 4(1)$. Other provisions of the English act that have no counterparts in American legislation make the English statute more comprehensive than any perpetuities statute recently enacted in the United States. See generally Lynn, Perpetuities Reform: An Analysis of Developments in England and the United States, 113 U. PA. L. REv. 508 (1965). The basic "wait and see" section of the English act reads as follows: "Where ... a disposition would be void on the ground that the interest disposed of might not become vested until too remote a time, the disposition shall be treated, until such time (if any) as it becomes established that the vesting must occur, if at all, after the end of the perpetuity period, as if the disposition were not subject to the rule against perpetuities . . . Perpetuities and Accumulations Act, 1964, 13 Eliz. 2, c. 55, § 3 (1).

12 California, for example, reformed the rule by enacting a "cy pres" statute in 1963. It provides that:

"No interest in real or personal property is either void or voidable as in violation of [the rule] ... if and to the extent that it can be reformed or construed within the limits of [the rule] . . . to give effect to the general intent of the creator of the interest whenever that general intent can be ascertained. This section shall be liberally construed and applied to validate such interest to the fullest extent consistent with such ascertained intent." CAL. Civ. CODE ANN. \$715.5 (Supp. 1964). California had recently returned to the common law rule. See Recent Legislation, 48 CALIF. L. Rev. 134 (1960). But this short-lived return was modified by the 1963 legislation, which repealed $\S \S 693,694$, and 695 of the Civil Code (defining vested and contingent future interests), and enacted $\$ \$ 715.5$ (establishing "cy pres"), 715.6 (establishing a sixty year period in gross), 715.7 (eliminating the "unborn widow" construction), and 715.8 (redefining a vested interest). CAL. Crv. CODE ANN. (Supp. 1964). The constitutionality and wisdom of $\$ 715.8$ have already been doubted. Review of 1963 Code Legislation, 38 CAL. S.B.J. 643 (1963); Comment, 16 Stan. L. REv. 177 (1963). The section was intended to abrogate the rule of Haggerty v. City of Oakland, 161 Cal. App. 2d 407, 326 P.2d 957 (1958), but while the legislature was acting, the Supreme Court of California was refusing to follow the rule of Haggerty in Wong v. Di Grazia, 60 Cal. 2d 525, 386 P.2d 817 (1963).

1s Several states have combined the "wait and see" and "cy pres" principles. For example, Kentucky's statute is as follows: "In determining whether an interest would violate the rule against perpetuities the period of perpetuities shall be measured by actual rather than possibie events; provided, however, the period shall not be meisured by any lives whose continuance does not have a causal relationship to the vesting or failure of the interest. Any interest that would violate said rule as thus modified shall be reformed, within the limits of that rule, to approximate most closely the intention of the creator of the interest." KY. REv. STAT. \$381.216 (1960). See generally Dureminier, Perpetuities law in Action: Kentucky Case Law and the 1960 Reform ACr (1962). Vermont has enacted a similar statute. VT. STAT. ANN. tit. 27, §501 (1959).

14 See Lynn \& Carpenter, Applying the Rule Against Perpetuities to Class Gifts: The Infuence of Leach, 43 TExAs L. REv. 37 (1964). 
Gray: "No interest is good unless it must vest, if at all, not later than twenty-one years after some life in being at the creation of the interest."1s Leach, who has tempered Gray's rule, ${ }^{16}$ suggests that this statement be preceded by the words "generally speaking," and that the word "vest" be put in quotation marks. ${ }^{17}$ The rule invalidates an interest that might vest, if it vests at all, at a remote time. A contingent future interest that might vest remotely, if it vests at all, is said to be "bad" or "void" or "invalid" under the rule. Although technically the rule is not concerned with interests so created that they must vest, if they vest at all, within the perpetuities period, it is conventional to say that a contingent future interest that must vest, if it vests at all, within the permissible period is "good" or "valid" under the rule. For example, if $A$, owning land in fee simple absolute, grants "to $B$ for life, remainder to $C$ and his heirs if $C$ attains 35," and $C$ is but twenty-one years of age at the time of the grant, the remainder in $C$ is contingent. ${ }^{18}$ The remainder in $C$ is not invalid under the rule because it is so created that it must vest, if it vests at all, within the lifetime of $C$, and $C$ is a "life in being" when the deed takes effect. Technically, then, the rule does not apply. Stated conventionally, however, the contingent remainder is "good" or "valid" under the rule. By contrast, if $A$ grants "to $B$ for life, remainder to that child of $B$ who first attains 35," and $B$ is a bachelor at the time of the grant, the contingent remainder is "bad" under the orthodox rule because it is not so created that it must vest, if it vests at all, within the perpetuities period.

Although it is sometimes said that any life can be used under the orthodox rule as the "life in being" at the creation of the con-

${ }^{16}$ Gray, The RULe Against Perpeturties 191 (4th ed. 1942). (Emphasis added.) Gray's statement has long been under attack: "Mr. Gray's statement of the Rule is ... inaccurate. It is the statement of an advocate, not of a judge." Sweet, The Monstrous Regiment of the Rule Against Perpetuities, 18 JuRID. REv. 132, 139 n. (a) (1906).

${ }_{10}$ See Lynn \&: Carpenter, supra note 14.

${ }^{17}$ Leach, Perpetuities in a Nutshell, 51 HARv. L. Rev. 638, 639 (1938).

${ }^{18}$ The remainder in $C$ is contingent at common law. In California the remainder vests in $C$ at its creation and is exempt from the Rule Against Perpetuities because of the following 1963 California legislation:

"An interest in real or personal property, legal or equitable, is vested if and when there is a person in being who could convey or there are persons in being, irrespective of the nature of their respective interests, who together could convey a fee simple title thereto." CAL. Crv. CodE ANN. $\$ 715.8$ (Supp. 1964). $A, B$, and $C$ could together convey a fee simple. The wisdom of this section has been questioned, see note 12 supra, and its repeal demanded. Comment, 16 Stan. L. Rev. 177, 190 (1963). 
tingent future interest to demonstrate its validity, ${ }^{10}$ that statement is accurate only in a limited sense and should always be read in context. Most lives will be totally irrelevant to the disposition and thus incapable of validating it (unless the draftsman provides $\bar{a}$ reasonable number of these otherwise irrelevant lives in being to be used for the express purpose of measuring the perpetuities period)..$^{20}$ On the other hand, neither a life not even mentioned in the dispositive instrument nor a donee of a gift under the instrument may be used to demonstrate validity. ${ }^{21}$ In the ordinary case, then, one must decide what "life in being" at the creation of the interest (if any) is to be used to demonstrate the validity of a contingent future interest under the rule.

Here the non-specialist gets little help from acknowledged authorities in future interests, ${ }^{22}$ and that is perhaps inevitable. Although the Rule Against Perpetuities did not attain its maturity until about the time that Gray published the first edition of his monumental work, ${ }^{23}$ it had been developing for more than two hundred years prior to that time. Lawyers and judges had had ample opportunity in a wide variety of perpetuities cases to illustrate how one casts about in a particular case for a "life in being" at the creation of the interest within whose lifetime (or within whose lifetime and twenty-one years) the questioned interest must vest, if it vests at all. Occasionally the facts are such that the twenty-one year period in gross alone can be used to demonstrate validity. But more commonly the process consists of choosing a life sufficiently comparable to that chosen in like cases in the past that a judge will concede the aptness of the life hit upon. Mechem admits the reliance we all place on learning by illustration when he says:

The question repeatedly asked is: how do you know which is the life in being? ... What the Rule [in orthodox form] requires is

10 "How do we determine the lives in being under the existing [orthodox] rule? The answer is, we may use any life as the measure, provided we can say, at the time the instrument takes effect, that, no matter what happens, the contingent interest will not vest later than twenty-one years after the termination of that life." Simes, Reforming the Common-Law Rule Against Perpetuities, in ABA PERPETUITX LeGiSLATION HANDBOoK 42, 44 (2d ed. 1962).

${ }^{20}$ There is no evidence that this practice is commonplace in the United States. See generally 6 AMERICAN LAW OF Property $\$ 24.13$ (Casner ed. 1952); 5 Powell, Real Property \$766(5) (1962); 3 Simes \& SMith, Future INTEREsts \$1223 (2d ed. 1956).

21 PowrLl, op. cit. supra note 20, at $\$ 766(4)$; authorities cited note 20 supra.

22 See, e.g., authorities cited notes 20, 21 supra.

${ }^{23}$ Gray, The Rule Against Perpetuitues (1886). 
that the challenged estate must necessarily vest within 21 years after the termination of some life either referred to or involved in the limitation. What is meant by "involved" may be illustrated [by example] .... . ${ }^{24}$

Having learned to give content to the expression "some life in being at the creation of the interest" by studying the cases decided by judges and expounded by commentators, how do we apply our learning to the solution of a perpetuities problem? Suppose that $A$ devises "to $B$ for life, remainder to that child of $B$ who first attains 35." Suppose further: that $B$ was a woman thirty-five years of age at the execution of the will and had a child or children alive at that time; that further children were born to $B$ before $A$ 's death; and that $B$ and one or more of her children are alive at $A$ 's death, no child of $B$ having yet attained thirty-five. $B$ is sixty-five years of age at $A$ 's death. The validity of the contingent remainder is questioned. If we construe "child of $B$ " to mean "child of $B$ alive at $A$ 's death," the remainder is good under the rule because any child of $\mathrm{B}$ alive at $\mathrm{A}$ 's death will attain thirty-five, or not, within such child's own lifetime. The remainder is demonstrably good although we cannot identify the "life in being" with precision at $A$ 's death. But suppose we give "child of $B$ " the common construction "child of $B$ whenever born"? Human experience in the western world ${ }^{25}$ tells us that $B$ will not conceive a child after $A$ 's death, but human experience includes information on the Rule Against Perpetuities in orthodox form, including the conclusive presumption of fertility. The test for the validity of a contingent future interest under the Rule Against Perpetuities in orthodox form is a possibilities test, not an actualities test or a probabilities test. $B$ might have a child after $A$ 's death. Such after-born child of $B$ might be the only child of $B$ to attain thirty-five, and he might attain that age more than

36 Mechem, Gases on Future InTerests 19 (1958). In this same connection, Professor Allan says, "From time to time, the perceptive student would ask 'But how do you find the lives in being?' and would be dismissed with an answer such as 'Well, they must be mentioned either expressly or by necessary implication in the limitation and they must not be too uncertain. Let's take a few examples and you'll soon get the hang of it.'" Allan, Perpetuities: Who Are the Lives in Being?, 81 L.Q. REv. 10607 (1965).

${ }^{85}$ An all-Pakistani team of scientists is undertaking a study of the longevity of the Hunzas of the western Himalayas. The team will try to discover why a Hunza woman can give birth to a baby when she is more than sixty years of age and why a Hunza man of ninety or more is virile enough to beget children. N.Y. Times, May 4, 1965, p. 25, col. 1 (city ed.). 
twenty-one years after $B$ 's death. Therefore, the contingent remainder is bad $a b$ initio under the rule in orthodox form although the only children who could ever in fact qualify for the gift are persons in being at $A$ 's death.

\section{II}

The Measuring Lives Under "Watr and SeE"

"Wait and see" legislation allows an interest to be viewed in the light of actual events, thus validating some gifts that would be invalid under the orthodox rule. Conversely, in some cases "wait and see" permits a declaration of the invalidity of a contingent future interest $a b$ initio by rejecting the conclusive presumption of fertility that has made the rule in orthodox form the butt of law students' jokes for generations. Suppose that $A$ devises "to $B$ for life, remainder to that child of $B$ who first attains 35 ," and $B$ is a bachelor at $A$ 's death incapable of conceiving a child at and after $A$ 's death. Under "wait and see" the inability of $B$ to conceive is a fact ${ }^{26}$ that justifies a declaration of the invalidity of the contingent remainder at $A$ 's death. ${ }^{27}$

Now suppose that $A$ devises "to $B$ for life, then to $B$ 's children for their lives, remainder to the grandchildren of $B . " B$ was a thirty-five-year-old woman at the execution of $A$ 's will, and had a child or children at that time. Further children were born to $B$ before $A$ 's death, and $B$ and one or more children and grandchildren are alive at $A$ 's death. $B$ is sixty-five years of age at $A$ 's death. "Grandchildren" is construed to mean "grandchildren of $B$ whenever and to whomever born." The gift clearly is bad under the orthodox rule. Under "wait and see," may a court at A's death declare the gift to the grandchildren valid $a b$ initio? Valid because the inability of $\mathrm{B}$ to conceive after A's death permits using the lives of the children of $\mathrm{B}$ to demonstrate that the ultimate number of the grandchildren who share in the gift will be fixed within "lives in being" at A's death? If the conclusive presumption of fertility is rejected in the case where the life tenant is a bachelor incapable of conceiving a child at and after $A$ 's death, it should be rejected where

${ }^{20}$ An "actual event" in the language of the Pennsylvania statute. See PA. STAT. ANN. tit. 20, \$301.4 (1950).

${ }^{27}$ Lynn, Raising the' Perpetuities Question: Conception, Adoption, "Wait and See," and Cy Pres, 17 VAND. L. REv. 1391, 1397-1403 (1964). 
$B$ is a woman sixty-five years of age at $A$ 's death. "Wait and see" sets the time limit within which a contingent future interest must vest, if at all, or fail under the Rule Against Perpetuities; "wait and see" does not tell us when the declaration of invalidity is made. And "wait and see" no more restricts us solely to declarations of the invalidity of contingent future interests than does the rule in orthodox form. Most importantly, it opens up to us the use of measuring lives to demonstrate the validity of limitations that traditionally were not available to us when working under the rule in orthodox form. In the preceding example, then, the gift to grandchildren is "good" under "wait and see," and if "wait and see" is coupled with "cy pres," no reformation of the gift is required.

Suppose that in the case just put, $B$ is a woman forty years of age at $A$ 's death, with a child or children and grandchildren then alive. Suppose further that $B$ is capable of conceiving a child at and after $A$ 's death. If "grandchildren" is construed to mean "grandchildren of $B$ whenever and to whomever born," the gift to grandchildren is bad $a b$ initio under the rule in orthodox form. It is bad $a b$ initio because the validity of the gift to grandchildren under the orthodox rule must be demonstrable as of the time of its creation irrespective of when the perpetuities question is raised. The lives of the children of $B$ alive at $A$ 's death cannot be used successfully to demonstrate the validity of the gift to the grandchildren because $B$ might have a child after $A$ 's death, and such after-born child might be the survivor of the children of $B$. Such after-born child might in turn have a child more than twenty-one years after $B$ and all of the children of $B$ alive at $A$ 's death have died. The possibility that the ultimate number of grandchildren who share in the gift might be fixed beyond the perpetuities period requires invalidating the gift to the grandchildren in its entirety under the orthodox rule.

Here "wait and see" relaxes the restrictions set on the choice of measuring lives by the orthodox rule's requirement that a contingent future interest be so created that it must vest, if it vests at all, within the perpetuities period. If $B$ is a woman forty years of age at $A$ 's death, and capable of conceiving a child at and after $A$ 's death, the validity of the gift to grandchildren cannot be demonstrated at $A$ 's death. But "wait and see" requires no demonstration of the validity of a contingent future interest at its creation. 
Demonstration of validity may be deferred under "wait and see" to a time beyond $A$ 's death. If all grandchildren of $B$ are in fact born within a period measured by the life of the survivor of $B$ and the children of $B$ alive at $A$ 's death and twenty-one years, the gift to grandchildren is good under "wait and see," and if "wait and see" is coupled with "cy pres," no reformation of the gift is required.28

\section{III}

\section{The Measuring Lives under "Cy Pres"}

Like "wait and see," the "cy pres" version of the rule implicitly rejects the conclusive presumption of fertility that is a characteristic concomitant of the orthodox rule. If $A$ devises "to $B$ for life, remainder to that child of $B$ who first attains 35 ," and $B$ is a bachelor at $A$ 's death, incapable of conceiving a child, reformation of the contingent remainder to read "remainder to that child of $B$ who first attains 21" would be futile because the gift would necessarily fail by its own terms. If $B$ and the successor in interest of $A$ wish to join in a sale of the land and marketability turns on securing a declaration of invalidity, a court should declare the contingent remainder bad under "cy pres." 29 Now assume the same limitations with the following variation on the facts. $B$ was a woman, thirtyfive years of age at the execution of the will, and had a child or children at that time. Further children were born to $B$ before $A$ 's death, and $B$ and one or more children are alive at $A$ 's death, no child of $B$ yet having attained thirty-five. $B$ is sixty-five years of age at $A$ 's death. May a court under "cy pres" refuse to reform the contingent remainder ${ }^{30}$ because the inability of $B$ to conceive after $A$ 's death permits using the lives of the children of $\mathrm{B}$ to demonstrate that the remainder will vest, if at all, within lives in being at A's death? If the conclusive presumption of fertility is rejected in the

\footnotetext{
${ }^{28}$ Whether deferring the determination of validity of the contingent future interest is a wise policy is not at issue here. For arguments that it is unwise, see Jones, supra note 7, at 58-65; Mechem, Further Thoughts on the Pennsylvania Perpetuities Legislation, 107 U. PA. L. REv. 965 (1959); Simes, Is the Rule Against Perpetuities Doomed7, 52 MICH. L. REV. 179, $184-90$ (1953).

${ }^{29}$ See Lynn, Raising the Perpetuities Question: Conception, Adoption, "Wait and See," and Cy Pres, 17 VAND. L. Rev. 1391, 1403-04 (1964).

${ }^{30}$ While the hypothetical case under discussion here can be differentiated from that considered in note 18 supra and accompanying text, it still might be argued that under $\$ 715.8$ of CAL. Crv. CoDE ANN. (Supp. 1964) the remainder is vested and exempt from the Rule Against Perpetuities. It is doubtless true that $B$, the children of $B$ alive at $A$ 's death, and the successor in interest of $A$ could effectively convey a fec simple.
} 
one case, it should be rejected in the other. "Cy pres" tells us that a contingent future interest, bad under the rule in orthodox form, may be reformed. "Cy pres" does not tell us that reformation will occur. In the example above no reformation of the remainder should be made. If a child of $B$ thereafter attains thirty-five, the remainder should indefeasibly vest in him.

\section{IV}

\section{The Measuring Lives in England}

The choice of lives in being at the creation of the interest for purposes of measuring the perpetuities period tends to be left open in American legislation. ${ }^{31}$ Perpetuities statutes in the United States tend to be short and catholic in scope. For example, the Vermont "wait and see" coupled with "cy pres" statute reads as follows:

Any interest in real or personal property which would violate the rule against perpetuities shall be reformed, within the limits of that rule, to approximate most closely the intention of the creator of the interest. In determining whether an interest would violate said rule and in reforming an interest the period of perpetuities shall be measured by actual rather than possible events. ${ }^{32}$

While the Kentucky "wait and see" coupled with "cy pres" statute expressly deals with the problem of measuring lives, it does so only in generalized language: ". . . provided, however, the [perpetuities] period shall not be measured by any lives whose continuance does not have a causal relationship to the vesting or failure of the interest."33

By contrast, sections $3(4)$ and $3(5)$ of the new English perpetuities reform act ${ }^{84}$ provide as follows:

(4) Where ["wait and see"] ... applies to a disposition ... the duration of the perpetuity period... shall be determined as follows:-

(a) where any persons falling within subsection (5) below are individuals in being and ascertainable at the commence-'

\footnotetext{
${ }^{31}$ In New Hampshire the development of perpetuities law is relatively unrestricted, because that state achieved its "wait and see" coupled with "cy pres" version of the rule by judicial decision. Merchants Nat'l Bank v. Curtis, 98 N.H. 225, 97 A.2d 207 (1953); Edgerly v. Barker, 66 N.H. 434, 31 Atl. 900 (1891).

${ }^{32}$ VT. STAT. ANN. tit. 27, \$501 (1959).

ss Ky. STAT. ANN. \$381.216 (1960).

st Perpetuities and Accumulations Act, 1964, 13 Eliz. 2, c. 55.
} 
ment of the perpetuity period the duration of the period shall be determined by reference to their lives ....

(5) The said persons are as follows:-

(a) the person by whom the disposition was made;

(b) a person to whom or in whose favour the disposition was made, that is to say-

(i) in the case of a disposition to a class of persons, any member or potential member of the class;

(ii) in the case of an individual disposition to a person taking only on certain conditions being satisfied, any person as to whom some of the conditions are satisfied and the remainder may in time be satisfied;

(iii) in the case of a special power of appointment exercisable in favour of members of a class, any member or potential member of the class;

(iv) in the case of a special power of appointment exercisable in favour of one person only, that person or, where the object of the power is ascertainable only on certain conditions being satisfied, any person as to whom some of the conditions are satisfied and the remainder may in time be satisfied;

(v) in the case of any power, option or other right, the person on whom the right is conferred;

(c) a person having a child or grandchild within subparagraphs (i) to (iv) of paragraph (b) above, or any of whose children or grandchildren, if subsequently born, would by virtue of his or her descent fall within those subparagraphs; (d) any person on the failure or determination of whose prior interest the disposition is limited to take effect.

It is apparent that under the Vermont or Kentucky statute, a court has more freedom to shape the law than has an English judge working within the confines of the new English statute. For example, if $A$ grants "to $B$ for life, remainder to that child of $B$ who first attains 35 ," and $B$ is a bachelor at the time of the grant, $B$ is the "life in being" in the United States for the purpose of measuring the perpetuities period under a "wait and see" or under a "wait and see" coupled with "cy pres" version of the rule. By contrast, under the English statute both $A^{35}$ and $B^{36}$ are "lives in being" for the purpose of measuring the perpetuities period. Suppose $B$ dies survived by an only child twelve years of age, and by $A$. The validity

\footnotetext{
${ }^{35}$ Perpetuities and Accumulations Act, 1964, 13 Eliz. 2, c. 55, $\$ 3$ (5) (a).

${ }^{80}$ Perpetuities and Accumulations Act, 1964, 13 Eliz. 2, c. 55, $\$ 3$ (5) (c).
} 
of the gift to the child of $B$ cannot be demonstrated at $B$ 's death, but it is clear that the child of $B$ cannot attain thirty-five within $B$ 's lifetime and twenty-one years. Yet reformation in England must be deferred. Three years thereafter $A$ dies, survived by the child of $B$. The child of $B$ will attain thirty-five, or not, within $A$ 's lifetime and twenty-one years, and under the English statute $A$ is a life in being. Reformation of the gift is unnecessary.

The provisions of the English act setting out measuring lives have been subjected to sharp criticism. ${ }^{37}$ They are undeniably complex. But that very complexity demonstrates professional dissatisfaction with the restrictions set on the choice of measuring lives under the rule in orthodox form. Such dissatisfaction is but a facet of a general discontent with the orthodox rule, with its requirement that a contingent future interest be so created that it must vest, if it vests at all, within the perpetuities period. The niceties of the English act are indeed annoying, and sections $3(4)$ and $3(5)^{38}$ should not be used as a model by other jurisdictions undertaking reformation of the rule. But in its insistence on a greater latitude in the selection of the measuring lives for the purpose of applying the rule, the English statute reflects the accelerating movement for relaxation of the requirements of the rule in whatever form it is remolded. Considered in that light, the provisions of the statute

${ }^{37}$ Morris \& Wade, Perpetuities Reform at Last, 80 L.Q. Rev. 486, $501-08$ (1964): "These subsections are of formidable complexity. They caused more difficulty in drafting, and underwent more vicissitudes, than any other part of the Act. ...

-...

" $\mathrm{A}$ first criticism is that the statute has cast its net so widely in order to cover every conceivable case that many quite inappropriate lives are included whose continuance has no relevance to the'vesting whatsoever. The result is to extend the "wait and see' period beyond what anyone contemplated and beyond what wise policy would seem to dictate. ...

"A second (and opposite) criticism is that relevant lives are sometimes excluded and the "wait and see" period unnecessarily restricted. ...

"A third criticism is that the statutory list applies not only to family transactions but also to commercial transactions. But lives in being have no significance in commercial transactions. ...

"A fourth criticism is that if there are no ascertainable individuals under section $3(5)$, the perpetuity period is twenty-one years only under section $3(4)(b) \ldots$

"We believe... that [the approach of the Act] ... to the problem of lives in being is wrong and that its detailed provisions are faulty. But for most practical purposes the provisions may still prove beneficial, and so justify the skill and care with which they have been drawn."

${ }^{38}$ Perpetuities and Accumulations Act, 1964, 13 Eliz. 2, c. 55. 
setting out measuring lives perform a worthwhile service, and the shortcomings of these provisions are not intolerable.

\section{ConcLUSION}

The choice of measuring lives for the purpose of demonstrating the validity of limitations under the Rule Against Perpetuities undeniably has been widened in those jurisdictions adopting a "wait and see" or a "cy pres" version of the rule. In England and New Zealand the expanded choice of measuring lives has been made explicit.39 In such jurisdictions as California, Kentucky, New Hampshire, Pennsylvania, and Vermont, the expanded choice is implicit.

The expanded choice of measuring lives originates in two sources: First, the acceptance of a "wait and see" or a "cy pres" version of the rule (or a combination of them) implicitly includes a rejection of the conclusive presumption of fertility that was a characteristic of the orthodox rule. In the English and commonwealth perpetuities reform statutes, ${ }^{40}$ that presumption is abandoned explicitly. This abandonment of the conclusive presumption of fertility makes lives relevant for the purpose of demonstrating validity that were necessarily disregarded under the orthodox rule.

Second, if at its creation neither the validity nor the invalidity of a contingent future interest can be demonstrated under "wait and see," determination of validity may be deferred, 41 and under some circumstances, determination of validity may be deferred to a time beyond the perpetuities period. ${ }^{42}$ Abandoning the requirement of the orthodox rule that a contingent future interest be so created that it must vest, if it vests at all, within the perpetuities period, permits the use of lives for the purpose of demonstrating validity that were necessarily disregarded under the orthodox rule because the course of future events, viewed as of the time the interest was created, could not be predicted with certainty. If $A$ devises "to $B$ for life, then to $B$ 's children for their lives, remainder

\footnotetext{
39 Perpetuities and Accumulations Act, 1964, 13 Eliz. 2, c. 55, $\S \S 3$ (4), 3 (5); Per * petuities Act, 1964, 13 Eliz. 2, No. 47, $\$ \S 8(4), 8(5)$ (N.Z.).

10 Perpetuities and Accumulations Act, 1964, 13 Eliz. 2, c. 55, §2; Perpetuitics Act, 1964, 13 Eliz. 2, No. 47, $\$ 7$ (N.Z.); Law Reform Act (Property, Perpetuities, and Suc. cession), 1962, 11 Eliz. 2, No. 83, $\$ 6$ (W. Austl.).

${ }^{11}$ See Lynn, $A$ Practical Guide to the Rule Against Perpetuities, 1964 DukE L.]. $207,220$.

18 See id. at 231 n.86.
} 
to the grandchildren of $B$," and $B$ is a woman forty years of age at $A$ 's death, with a child or children and grandchildren then alive, the ultimate number of grandchildren sharing in the gift to them might be fixed within twenty-one years after the death of the survivor of $B$ and the children of $B$ alive at $A$ 's death. But the inability to postulate at $A$ 's death that the survivor of $B$ and the children of $B$ will be drawn from $B$ and the children of $B$ alive at $A$ 's death, precludes using the lives of the children of $B$ alive at $A$ 's death to demonstrate that the gift to grandchildren is good under the orthodox rule.43 Under "wait and see," however, those lives may be the ones ultimately used to demonstrate validity.

Examination of the new English and commonwealth perpetuities legislation underscores a point that began to emerge when the Pennsylvania perpetuities reform act was adopted in 1947: perpetuities reform statutes should be short, and cast in familiar terms. The objective of the legislation having been set, be it adoption of "wait and see" or "cy pres" or some combination of them, the statutory language proposed for adoption should build on the structure created by Gray and should be as concise as possible consistent with attaining the objective sought. Because it is exceptionally difficult to draft perpetuities legislation that anticipates every twist and turn of an admittedly abstract expression of public policy on dead-hand control of wealth, filling in the detail of legislation should be left to the courts.

Although Gray's statement of the Rule Against Perpetuities has not been universally acclaimed, attempts to improve upon it have not been particularly successful, and it is now an integral part of our common law heritage. Whatever the rule might have become, it was in flux when Gray wrote. If Powell is correct in his assertion that Gray's conception of the rule is too narrow, ${ }^{44}$ then Gray not only made the rule a rule against remoteness of vesting but also demonstrated most convincingly that sheer effrontery makes law, for Gray's conception of the rule is generally accepted today. ${ }^{45}$

\footnotetext{
"s Of course the gift would be valid if "grandchildren" were not construed to mean "grandchildren whenever and to whomever born."

«" "By [Gray's formulation of the rule] ... the profession has been misled to believe that the rule now concerus, and in the past did concern, only remoteness of vesting." Powell, Nutshells and Perpetuities, 7 U. CHI. L. REv. 489, 492 (1940).

106 ameriean law of Property $\$ 24.3$ (Casner ed. 1952); 3 Simes \& Smith, Future INTERESTS $\$ 1222$ (2d ed. 1956).
} 
A simple form of "wait and see" is in substance a variation of Gray's statement of the rule: "No interest in real or personal property is valid unless it vests, if at all, not later than twenty-one years after some life in being at the creation of the interest." This statement of "wait and see" is subject to the criticisms leveled at Gray's statement of the orthodox rule. But it avoids the use of unfamiliar expressions such as "actual events" 46 and "causal relationship." 47 It does what it is intended to do: It reforms the Rule Against Perpetuities in orthodox form. It does not cast lawyers and jurists into a new and uncertain area where many errors will occur before the law becomes well-defined.

If "cy pres" is to complement "wait and see," a single line can be added: "An interest that violates the Rule Against Perpetuities shall be reformed to give effect to the general intent of the creator of the interest and to comply with the requirements of the Rule Against Perpetuities."

Regardless of the precise formulation of the perpetuities reform statutes, they should be read whenever possible as statements of policy and should be stretched to their limits in order to achieve sensible results. It is doubtless true that the more abstruse principles of property law will continue to be used by a relatively small segment of our total population, that they will continue to constitute "rich men's law," and that they will evoke little general interest. Even so, they ought to work well. The degree of freedom accorded to judges by the rules of construction and by the intricacies of the Rule Against Perpetuities itself, is unquestionably great; but unless we are to pay no more than lip service to the relative freedom of disposition which our society permits, we should not use the Rule Against Perpetuities as a substitute for legislation which gives a forced share of a decedent's estate to the natural objects of his bounty. The rule is ill-designed for accomplishing anything more than its primary task.

Even if we could demonstrate conclusively that Gray's view of the rule (as a rule only against remoteness of vesting) is a misconception, we cannot undo three-quarters of a century of legal learning. The best we can do is to build upon what we have. The perpetuities reform statutes are a beginning.

${ }^{6}$ See Pa. Stat. ANN. tit. 20, $\$ 301.4$ (b) (1950).

${ }^{47} \mathrm{KX}$. REv. STAT. $\$ 381.216$ (1960). 